\title{
Increasing the popularity and efficiency of distance education by old-new methods
}

\author{
RÓBERT PÁNTYA and LÁszló MuCsics F.
}

Abstract. In our essay we aim to provide suggestions to develop distance education and we decisively focus on programmed education that is supported by e-learning environment. We both think that the shortage of programmed educational methods is causeless in Hungary's distance education. The widespread usage of info-communication devices and of the Internet makes the programmed educational methods (not as an exclusive method) possible to use in distance education together with e-learning environment. In our work we summarize the possible solutions and at the same time we also provide a case study, as an insight into our e-learning project (called Logical Programming) by Moodle.

Key words and phrases: distance education, e-learning, programmed education, logical programming.

ZDM Subject Classification: B40, P40, Q60, U50.

\section{Introduction}

Distance education in higher education as a form of teaching is said to be overshadowed in the last few years considering both its proportion and its numbers. While in 2001 the ratio of first-year undergraduates learning in distance education was $11.8 \%$, this number in 2009 is only $2.4 \%$. As far as the absolute numbers of first-year undergraduates are concerned the same recidivation can be observed as in 2001 the number of students learning in distance education was 11553 while in 2009 it was just 2557 (this is shown in Figure 1 and Figure 2) [1].

Copyright (C) 2010 by University of Debrecen 
Of course, it is due to several reasons: e.g. the multitudinous applications of those who earlier missed their higher education have ended; the Bologna process has had negative impacts on the learning attitude of the older generations; and future students prefer choosing professional trainings where the government plays active role on financial subsidy. The ratio of those whose education is financially supported by the government is rising from year to year but we must also mention that $1 / 3$ of the freshmen have to pay individually for their own education [2]. Besides these reasons we also think that it is also valid to state that the earlier forms of programmed distance education regarding its methods, tools and arguable efficiency can be blamed for not gaining ground in our higher education. We focus in our examination on how; in what ways the forms of distance education could be made again popular. We try to find answer to what methods, what educational technologies were useful to make distance education attractive. Based on foreign examples we also share the idea of those who think that the educational form is right before a huge and tremendous change. In our study we give an insight into the info-communication devices of households in the last couple of years. We summarize the main criteria of distance education, and examine the advantages of programmed education and of e-learning. We introduce the main sketches, features of Moodle, and we aim to provide a possible application of programmed education in distance education. Finally, we show in detail one online course (Logical Programming) of ours.

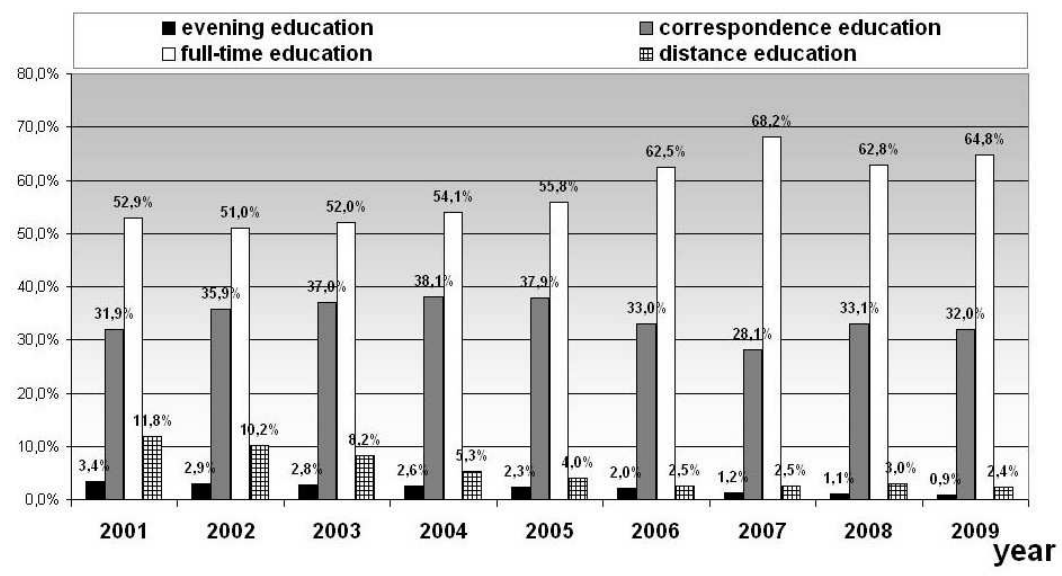

Figure 1. The relative distribution of first-year students according to their form of training (2001-2009) [1] 


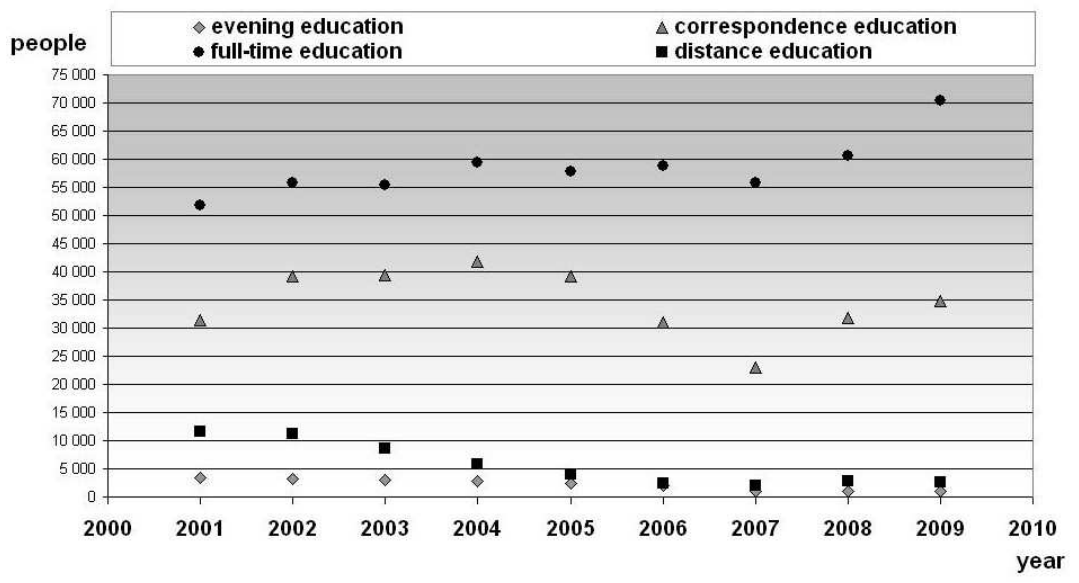

Figure 2. The absolute numbers of the first-year sudents in different forms of aducation (2001-2009) [1]

\section{Info-communication devices of population}

The fast growth of the Internet and the rapid development of info-communication tools have great impact on everyday life (e-commerce, bank operations, and electronic administration) and its effects are significant in education, too. We call the attention to some really important facts based the data produced by the Hungarian Central Statistical Office. The fast spreading tools of infocommunication in households and their usages are shown in Figure 3 and Figure 4.

It is crucial to remark from Figure 3 that in 2009 the ratio of those households that possessed PCs was $56.8 \%$, the ratio of households that have Internet connection was $55.1 \%$, and what is also important to the success of e-learning that the ratio of households with broadband Internet connection was $50.9 \%$. As these data refer to the total population of Hungary we are entitled to say that these data are higher among those groups of people who are or will be active members of higher education. This figure does not show the ratio of households equipped with cell phones as the ratio of households equipped with at least cell phone in 2009 is $90.4 \%$. [3]

The Figure 4 shows in detail the usage of these devices. It is important to note the ratio of e-commerce also shows significant growth. The word 'user' in the survey refers to those people who used computers, the Internet or their services in the last 3 months. 


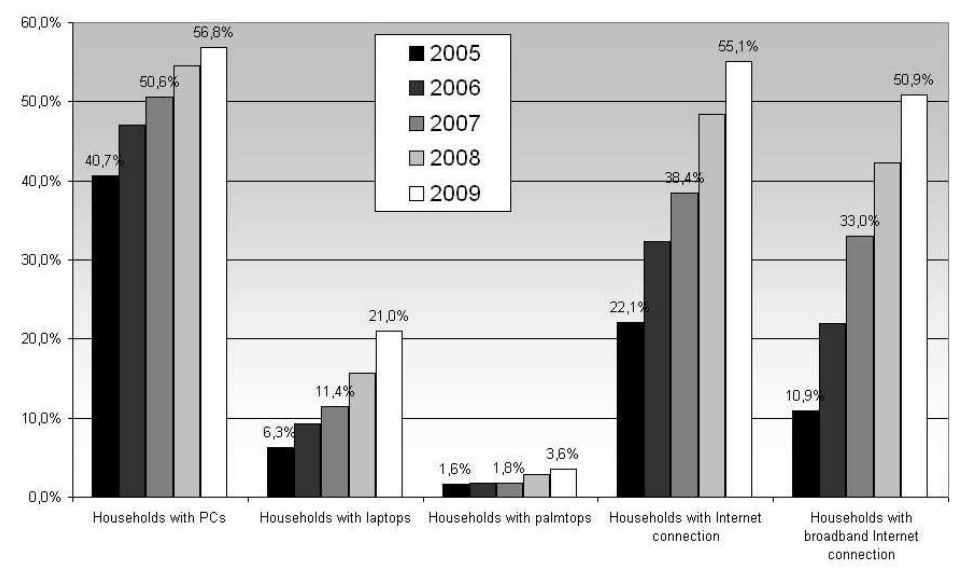

Figure 3. Info-communication devices of households (2005-2009) [3]

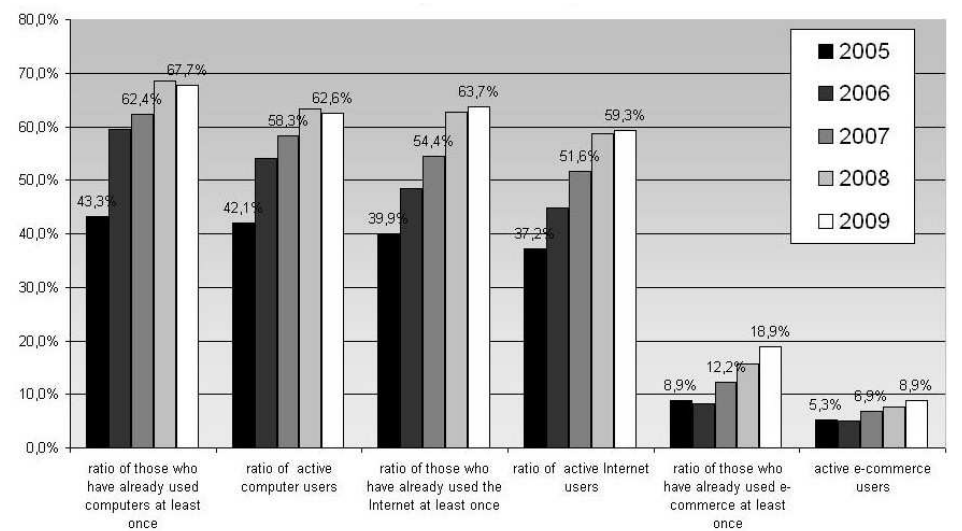

Figure 4. Using of info-communication devices of households (20052009) [3]

The Figure 5 shows the total number of Internet subscriptions in the given year. It can be clearly seen that in the last 5 years, the number of Internet subscriptions has almost quadrupled (in 2003 the number of subscriptions was 666592 , while in 2008 it increased to 2310 914) [4]. 


$$
\text { "tmcs-pantya" — 2010/11/14 - 21:46 — page } 215 \text { — \#5 }
$$

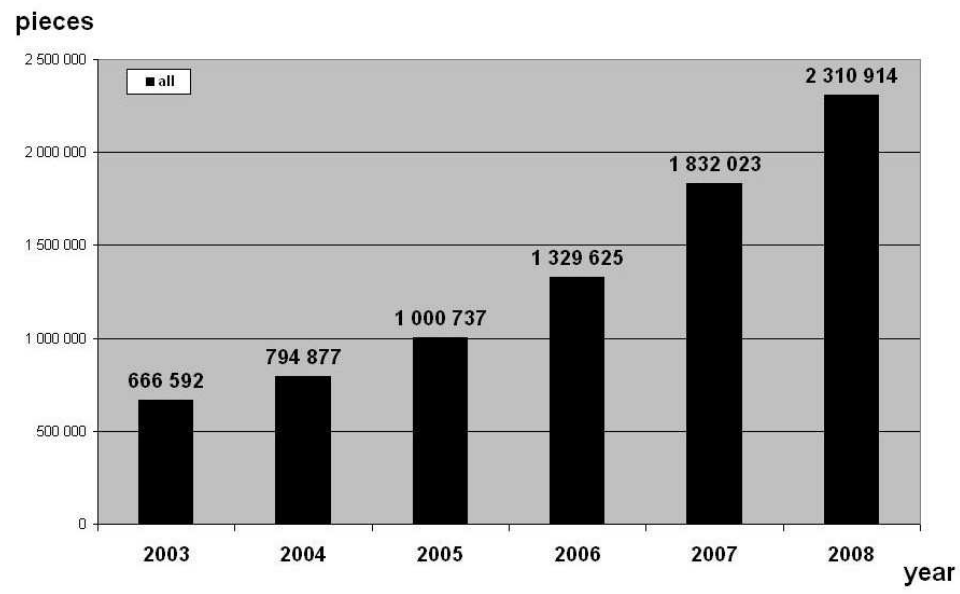

Figure 5. Number of the Internet subscriptions (2003-2008) [4]

3. The utilisation of programmed education in distance education with the help of e-learning

In the previous chapter we could see that the tremendous growth of infocommunication tools together with the expansion of Internet is really significant in Hungary. It has serious effects on education, too. Today we are facing the paradox situation that the number of undergraduates in distance education has declined by the time when it would be the easiest to carry out. As all basic necessities are given we think that with the application of e-learning in higher education we will experience the expansion of distance educational forms. This chapter we show the basic features of distance education, of programmed education and of e-learning. Furthermore, we also provide the most typical parameters of Moodle. Finally, we provide solutions to the realisation of e-learning courses.

\subsection{Distance education and programmed education}

According to Csoma Gy. [5] distance education is one realisation of remote control of learning. He states that distance education continuously directs and comprehensively organizes the procedure of learning in a step-by-step mode.

Kokovay Á. [6] summarizes the main elements of distance education: 
- "in distance education personal relationship between the instructor and the learner is modified; sometimes it is totally diminished,

- the process of learning is directed, controlled,

- in the direction of learning personal relationships are substituted by group of media set,

- learners are given regularly chosen and compiled material,

- motivation has an outstanding magnitude,

- in the process of learning the learner endeavours to individuality,

- the process of learning is justified to the abilities and circumstances of the learner to great extent".

So, we can state that distance directing has crucial role in distance education. Programmed education is one of the best methods for indirect controlling and for individual learning. Appropriate programmed materials also provide useful feedback during the procedure of learning. According to A. Vincent [7] creating programmed educational materials is quite exhaustive work but the effects it causes at the users, at the learners (interest, cheer mood) compensates the developer. L.N.Landa [8] suggests that complicated material should be taken into small elementary parts until it becomes so understandable that all users can absolve them unambiguously.

According to Tóthné Köröspataki Kiss Ágnes [9] "programmed education is kind of individualised education where learners are to follow a well-planned program steps that through an algorithm, leads the learners to achieve the final goal. Programs ensure the scheduled progress to each individual and also contain the constant possibility of self-evaluation". Its real advantage that it provides the security of individual learning to those who possess learning/acquiring difficulties as making mistakes is not revealed before the other users [9]. Programmed education reached its heyday in the middle of the $20^{\text {th }}$ century. Due to the World War II programmed education was first on scene in military trainings in the Western European countries. It arrived in Hungary only in the $60 \mathrm{~s}$, but its mainstream can only be dated to the 70 s [10].

Advantages of programmed education:

- well-constructed educational syllabus, lecturer program,

- a great number of direct feedback to the learners, possibilities for self-evaluation,

- based on robust individual work, requires active cooperation of the learner, 
- individual progress according to personal skills and abilities,

- economical, as it requires little teaching staff for crowds of learners.

Disadvantages of programmed education:

- it minimizes the pedagogical contribution,

- single-lined,

- evaluation (in case of self-evaluation) cannot use and handle human language (possible answers are to choose from a given set of answers),

- mental rigidity,

- it suppresses intelligent activity, as it can constrain the development of alternative cogitation,

- it may distract students away from creative thinking.

After examining the advantages and disadvantages of programmed education we can state that programmed education is available for acquiring complicated learning material in basic and simple units, for training simple (routine) exercises and for evaluating the required material. It can be extremely useful in levelling the heterogeneous knowledge (for those who leg behind the average). Taking these into consideration we think that programmed education in higher education is indispensable. In the next chapter we briefly summarize the specific features of e-learning, and of Moodle, and possible realisations of programmed education via Internet.

\subsection{E-learning}

Komenczi B. states that [11] "e-learning endeavours to improve the efficiency of acquiring knowledge by an effective combination of computers, network databases and Internet communication". According to Clark and Mayer [12] elearning is a computer application that:

- contains complex educational methods, which common aim is to promote the procedure of learning through simple and complex exercises,

- handles contents relevant to the specific feature of acquiring knowledge,

- it uses different media elements (picture, voice, video) where the primary aim is to transmit knowledge,

- it constructs knowledge and abilities through which the learner is able to achieve better performance. 
Kokovay Á. [6] states: "e-learning is more than distance education systems with two basic elements:

- the learning material is available for the learners in electronic forms,

- the means of transmission in the Internet, or the Internet networks".

E-learning is connected to distance education, computer-based education and web-based education. This relationship is shown in the Figure 6 by Komenczi B. [11].

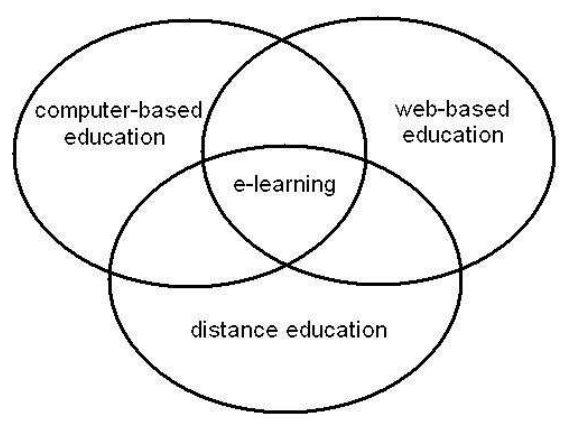

Figure 6. Ingredients of e-learning [11]

It can be clearly seen that e-learning can not be identified equally with any of the participants, that is, it is equal neither computer-based learning, nor with Internet web-based learning. E-learning is a new way of teaching method that contains parts from the previously mentioned educational techniques and yet it means something absolutely new that has never existed before.

M. J. Rosenberg [13] summarizes the most important advantages of e-learning:

- material content is easy to modify, information can be refreshed easily any time,

- accessibility is $24 / 7$,

- it possesses great community developing feature, which is huge motivation factor,

- in case of sudden growth in the number of users it can be easily resized,

- provides significant increase in the performance of the users,

- economical (despite the high costs of the early stages).

The most determinative disadvantage of e-learning is that it can only be utilised in a given info-communication infrastructure. It also means that the 
"tmcs-pantya" — 2010/11/14 — 21:46 — page 219 — \#9

Increasing the popularity and efficiency of distance education by old-new method

shortage of adequate computers or the lack of broadband Internet prevents the application of e-learning. The physical presence of these technical devices is still not enough as users must be in the possession of digital literacy to be able to use e-learning successfully.

\subsection{Moodle}

Realising efficient e-learning is promoted by other tools, techniques and technologies. One of the most dynamically developing tools of e-learning is called Moodle, which is an open source-code, free software. Moodle is an acronym; it is for Modular Object-Oriented Dynamic Learning Environment. It has been translated into more than 70 languages and has been widely used in 196 countries of the world [14]. As for the suitable server for Moodle the following environment is required: Apache web server, PHP script language and MySQL database server. Furthermore, an operation system is also required (e.g.: Unix/Linux, Windows $\mathrm{XP} / 2000 / 2003$, MAC OS X). As far as the user's part is concerned, they need to have an optional web-browser (e.g.: Mozilla, Firefox) [15]. The basic services of Moodle are content management and content development, course organisation and communication.

The most important services of Moodle:

- content management (SCORM materials, database management, e.g. selftailored educational video files, online videos on video-shares, online logic and simulation games, e.t.c.),

- communication possibilities (chat, forum, electronic correspondence, Skype),

- control and self-evaluation methods (lessons, tests, collection of notions). [16]

Moodle cannot only be used in distance education but in full-time and correspondence training as well. In such situation we can talk about blended learning rather than e-learning. Blended learning is a mixed form of education that combines the traditional method of teaching with the online learning techniques. The combination of the two teaching methods can efficiently utilize the advantages of both techniques [17].

Considering the previously discussed topic we can state that e-learning and Moodle is a rightful tool for distance education. Moodle is an easy-to-handle, economical way of teaching and it also combines all the different possibilities that make teaching methods possible to realise. Its great advantage is that Moodle supports the mixed methods of education and any of the methods will become overwhelming during education. So, from now on it is only the institution, or 


$$
\text { "tmcs-pantya" — 2010/11/14 — 21:46 — page } 220 \text { — \#10 }
$$

rather the creativity of the instructor who can utilize the advantages of the different methods and can eliminate the disadvantages of each method.

\subsection{Suggestions for ideal solutions}

In this part we are going to summarise the criteria and suggestions for methodological solutions which we consider indispensable for effective and popular distant teaching. We believe that this ascertainment can serve as guidelines for the organisation of such courses.

We consider it of utmost importance to accurately compose the educational objectives, to precisely determine the syllabus of the curriculum, and to make the necessary preliminary knowledge known at the very beginning of the organisation of the course. It is important to make the compulsory material accessible (which summarises the material of the given subject either in electronic and/or printed form). It is also advisable to set the minimum requirements (e.g. minimum concepts in the collection of basic terminologies, providing access to entrance tests, present samples for student's presentations, home assignments which must be submitted, requirements for programs, etc.).

The main body of the curriculum should be processed in the lessons that follow the programmed methodology, which facilitates the ideal pace of progress based on individual abilities. A great advantage of Moodle is that these lessons are not only simple to create but can also be easily modified (it is not rigid) if a problem arises which causes difficulties for a number of students; e.g. it offers easy solutions for correction when common wrong answers are given to certain questions. This was unthinkable with expensive educational CDs or previously issued programmed textbooks published in large quantities. Furthermore, it is also crucial to remark, that the acquisition of the required material is further monitored by the method called Conditional Activities. Students can only move further if they have accomplished the required level promoted by the lecturer [18]. It is important to integrate communication tools (e-mails, chat, Skype, msn, and forums) into a common framework. Consultations must also be available both via the Internet (Skype, msn) and personally at given times.

Small group activities do not necessarily mean working and meeting solely with the teacher. Since the participants can reach one another, they can get in touch on their own. Students may not live far from one another thus there is a way for personal meeting which means that not only virtually can a group or small community be established. This type of connection is indispensable because we can very often observe that the students who cannot keep pace with the group 


$$
\text { "tmcs-pantya" — 2010/11/14 — 21:46 — page } 221 \text { — \#11 }
$$

become isolated and feel they have to fight with the "elements" on their own. The establishment of these student groups (may there be virtual or personal) must be facilitated, stimulated. Programmed education enables teaching large number of students economically; nevertheless, we must be familiar with its drawbacks as this is not an exclusive method. However, Moodle, which effectively supports constructivist pedagogy, helps in the elimination of these problems. [19]

As said by Bessenyei and Tóth [20]: "according to the theory of constructivist learning students develop their knowledge by formulating new information according to their previous experience and understanding. According to this theory students are not empty "vessels" which must be filled with already existing knowledge but people who participate in developing their knowledge. Should the education in schools be able to grasp and map the complex, ramifying and individual needs, it would be more successful than the previous, rigid structures." Of the large number of Moodle tools supporting constructivist pedagogy we must accentuate the forum, wiki, collection of basic terminologies, database and messages possibilities by means of which knowledge sharing and the pooling of technical experience. Besides, it is very easy to take advantage of the multimedia services of Moodle. Thus whatever is worth demonstrating should be demonstrated e.g. by home made videos, rich illustrations, useful diagrams, materials from the Internet, online games, etc. Teachers must prepare to be able to provide new materials for well-performing talented students as well and make sure not to divert pupils from creative thinking but initiate and set common tasks, too.

Constructivist pedagogy, together with the large selection of multimedia possibilities, enables the elimination of the drawbacks of programmed education. Moodle allows (and requires) the active participation of teachers, and at the same time knowledge sharing and the pooling of technical experience accelerate the intellectual activity of students, require creative thinking (this way intellectual rigidity and unidirectional decrease in the teaching-learning process). It is very important to follow how solutions are achieved in tests, students do not do their tests only for "themselves", the teacher can also see how student have fared and whether they have dealt with the home assignments. (These attempts are hidden from other students; only the teacher is authorised to access them.) It is important that students do not feel lonely during the course of the training, they should always be aware that their activities are supervised by the teacher and knows who has done what and when or what has been omitted (this may be encouraging and, of course, calling to account).
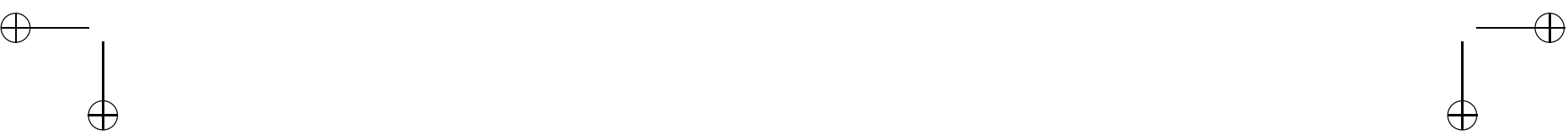


$$
\text { "tmcs-pantya" — 2010/11/14 — 21:46 — page } 222 \text { — \#12 }
$$

The effective and sensible use of lessons and tests are indispensable for the success of this method, as explained by Bakó [21]: "the students' attitude is greatly altered when they feel the sword of Damocles is above their head, so if they do not just play with the tests but know that the teacher is informed about each and every solution."

We must make sure that exams are not composed solely of multiple choice tests. Filing out multiple choice test papers cannot be suffice to acquire adequate knowledge in a given topic, students must be able to prove their knowledge in a written or oral form (or in the case of programming in practice) as well. Questions raised during lessons may be answered by making students write the answer on a piece of paper so that they can check the solution individually. Thus this method shifts away from the critical position which enables only multiple choice questions and we may proceed knowing that it is worth accustoming students to strict self-assessment.

\section{Educational possibilities of Logical programming in e-learning system}

This chapter aims to provide a possible solution to construct a course, which has already been tested in blended learning environment [22]. The Moodle elearning system of Károly Róbert College is available for our students and lecturers at polihisztor.karolyrobert.hu [23] website. Enrolling for a course requires registration.

The aim of the course called "Logical programming" is to develop the problem solving skill of the students. Another aim of the course is to get students acquainted with the declarative programming with the help of Win-Prolog 4.700 [24]. During the course we concentrate on teaching programming through exercise-oriented methods. Besides we apply case studies as well as a great number of examples [25]. As acquiring the logical programming is not an easy task we also regard it very crucial to apply different tools in education. The main window of the course can be seen in the Figure 7 .

On the top left part of the main window we can reach the participants; we can send messages, emails, to our students or to our group of students. A calendar also appears in the main window (on the right) that contains the course events (mid-term papers, end-term papers, visiting hours, exam dates e.t.c.). The central middle part "Logical Programming" contains the most important technical, communicational and organisational issues. This is the area where the 


$$
\text { "tmcs-pantya" — 2010/11/14 — 21:46 — page } 223 \text { — \#13 }
$$

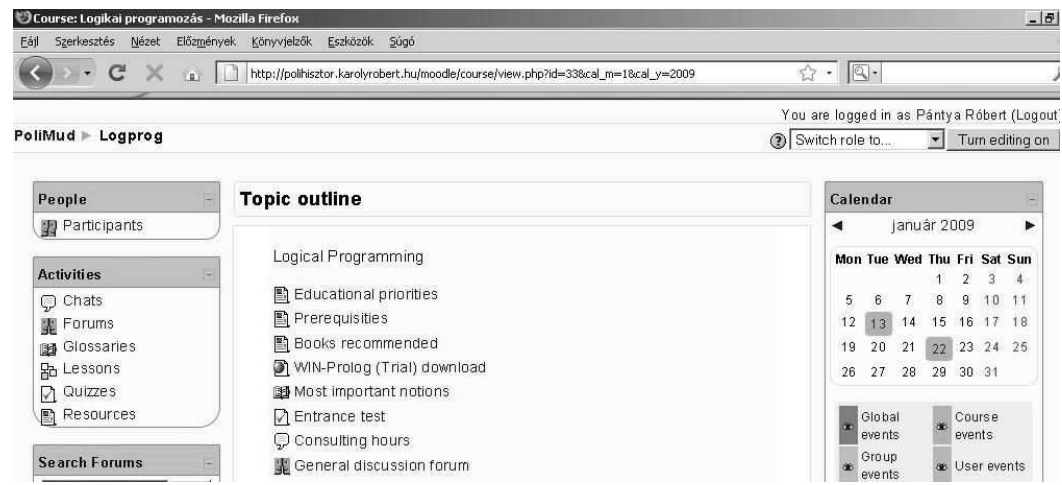

Figure 7. The main window of the course "Logical programming" [23]

course members can find all the relevant information (aim of the course, required prerequisites, recommended books, information on how to download the program language). The basic notions of the course are collected in the "Most important notions". We can create tests from these definitions that can be used later at the end of each section (Knowledge test) and at the end of the term for evaluations. Students may also test their complex knowledge by clicking on "Entrance test". We also operate a general discussion forum; and in a given time we have online consulting hour where we use the telephone service of Skype. All topics possess lessons, downloadable files that can be pdf documents, self-tailored videos to the usage of the program language, source files of programmes. The main body of the required educational material is placed in lesson format. Each topic is provided with a "Knowledge test" and letting the students tell their opinions, suggestions we placed forums at the end of each topic. Tests are available for the students only if they passed through the materials and achieved the required results (Conditional Activities). In the Figure 8 we can see the detailed list of the course topics as they can be seen by our registered participants.

We started teaching Logical Programming in the section called "Prolog bases (facts, rules, target statements)". In this chapter our students get acquainted with syntactic basis of Prolog and meet some very simple exercises. This introductory part contains two lessons that follow the teaching methodology of programmed education. With Camtasia screen recorder program we created a video in the chapter called "Early steps in WIN-Prolog". This chapter gets students acquainted with the basic techniques of programming method. Just like at the other chapters "Knowledge test" is also possible for the user to test his 


$$
\text { "tmcs-pantya" — 2010/11/14 — 21:46 — page } 224 \text { — \#14 }
$$

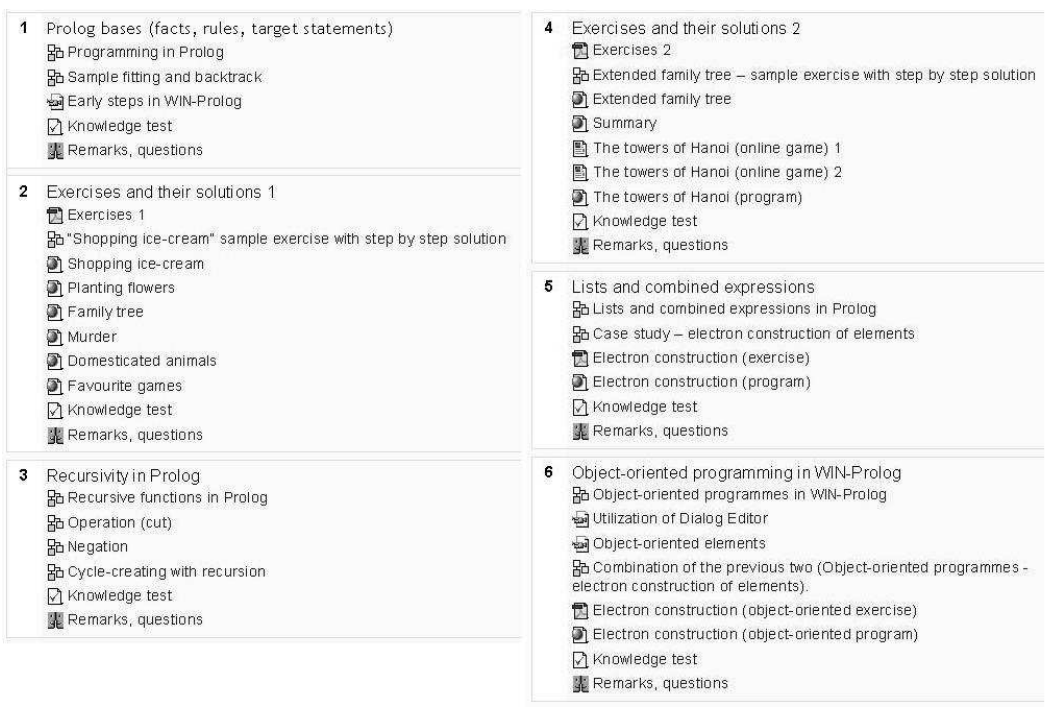

Figure 8. Topic of the course "Logical programming" [23]

or her knowledge. The aim of "Exercises and their solutions 1" is to provide practice material with sample examples. Exercises are available in pdf files, while source-programmes are in downloadable formats. "Recursivity in Prolog" chapter is to show more complicated programs structures. This is known as a rather problematic area of "Logical Programming". That is the reason why we placed the most lessons (Recursive functions in Prolog, Operation cut, and Operation negation, Cycle-creating with recursion). We think that this is the chapter where the instructor's directing role in individual acquisition is the most significant.

"Exercises and their solutions 2" aims again to achieve deeper understanding of the previously taught material (with sample exercises). Acquiring recursion is promoted by exercises where solutions are also provided. To find the solution of one of "the most famous" example known as "The towers of Hanoi" is supported by online logical games that are available on the Internet [26], [27]. It is worth making it available as the rules of the game can be considered well-known at the time of its programming. We experienced that if students are involved in the activity of experimenting than they can achieve better results. Several other online games are available on the Internet (Nim game, placing 8 queens, 8 and 15 puzzles). In Moodle these websites can be easily grouped. The chapter 


$$
\text { "tmcs-pantya" — 2010/11/14 — 21:46 — page } 225 \text { — \#15 }
$$

"Lists and combined expressions" provides information on more complicated dataconstructions. Here we use a case study on the elements electron-construction (it had been worked out earlier) [28]. This helps a lot to demonstrate lists and the usage of other combined expressions. Finally, the chapter "Object-oriented programming in WIN-Prolog" gets students acquainted with the usage of visual program elements in logical programming environment. New learning material is taught by two video files (Utilisation of Dialog Editor, Creating Object-oriented elements). This part is very important because earlier Prolog versions did not contain object-oriented extension thus it was very difficult to motivate students. In this Prolog version it is very easy to create object-oriented programs. In this chapter the case study (called electron construction of elements) can be done by object-oriented way [28]. The main body of the course is built by lectures that follow the methodology of programmed education:

- Programming in Prolog,

- Sample fitting and backtrack,

- "Shopping ice-cream" sample exercise with step by step solution,

- Recursive functions in Prolog,

- Operation cut,

- Negation,

- Cycle-creating with recursion,

- Extended family tree - sample exercise with step by step solution,

- Lists and combined expressions in Prolog,

- Case study - electron construction of elements,

- Object-oriented programmes in WIN-Prolog,

- Combination of the previous two (Object-oriented programmes - electron construction of elements).

In these lessons we placed control questions; if students do not know the right answer these questions than they can follow more detailed path in the acquisition of the learning material.

After providing the correct answer students may carry on with elaborating the rest of the lesson. Figure 9 demonstrates certain steps from the flow chart of the case study (electron construction of elements). At the $2^{\text {nd }}$ step the next slide depends on how the student answers. If the undergraduate chooses the right answer he may go on (down). But in case of wrong answer he is given an extra 
slide with a deeper explanation of his mistake then he gets back to the question of the $2^{\text {nd }}$ step.

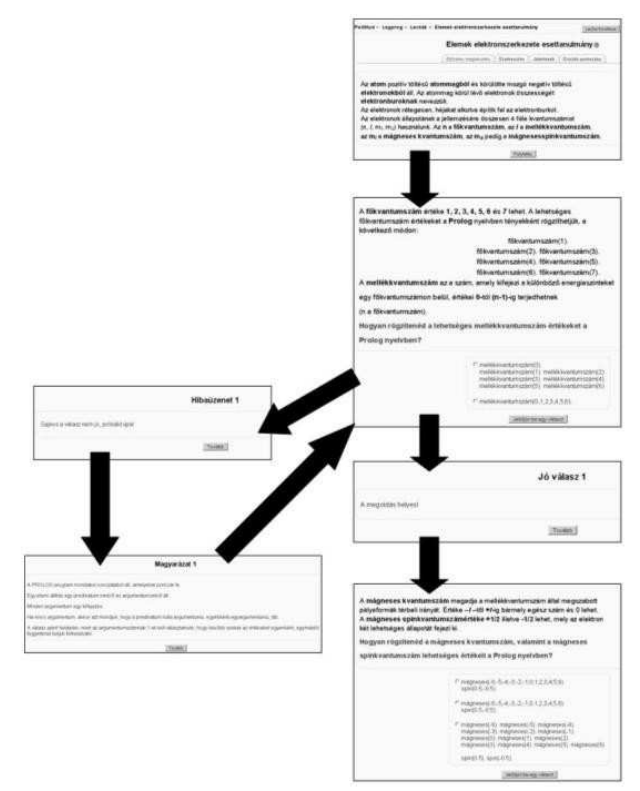

Figure 9. Part of the flow chart of the case study [23]

At the end of each chapter students may check how much they have understood the material with the help of "Knowledge test". Knowledge control and evaluation has several different methods in Moodle. One of its most important representatives is tests. Tests prove to be very useful in evaluating students. Individual learning is also helped by these feedbacks. The Moodle system offers a great choice of tests thus we can choose multiple choice, single choice, single number, pairing, calculating tests. We use these tests as entrance tests for the real exams.

It is crucial to remark that the results of the tests can only be seen by the student and his teacher. Tests are available $24 / 7$ with new questions as question tests are randomly chosen from a huge database. The instructor can see the result in table format and the number of tests, thus the lecturer may get feedback information on solvability of the learning material. The students' results may be analysed statistically. 


\section{Summary}

In our study we examined the number of students learning in higher education and experienced that both the ratio if distance education and the number of students in distance education declines. Examining the info-communication devices of households can realise that due to rapid technological development there seems to be a serious possibility to use e-learning in distance education.

Based on our examination we strongly advise using the method of programmed education in distance education to achieve higher popularity and bigger efficiency. The shortages of programmed education can be handled with e-learning that's why we urge its application.

\section{References}

[1] www.felvi.hu, Statistical data of previous years (2001-2009) (in Hungarian), 2010, http://www.felvi.hu/felveteli/ponthatarok_rangsorok/elmult_evek.

[2] Fábri I., General features of students admitted in 2008 (in Hungarian), 2009, http://www.felvi.hu/felsooktatasimuhely/kutatasok_rangsorok/Hallgatok/ a_2008ban_felvetelt_nyert_hallgatok_altalanos_jellemzoi_?itemNo=2.

[3] Hungarian Central Statistical Office, STADAT 4.7.14. ICT usage in households and by individuals (2005-), 2010,

http://portal.ksh.hu/pls/ksh/docs/eng/xstadat/xstadat_annual/tabl4_07_14ie.html.

[4] Hungarian Central Statistical Office, STADAT 4.7.8. Number of the Internet subscriptions by access services (2003-), 2010,

http://portal.ksh.hu/pls/ksh/docs/eng/xstadat/xstadat_annual/tab14_07_08ie.html.

[5] Csoma Gy., Lexicon of Adult Education (in Hungarian), Kossuth Publishing House, Budapest, 1987.

[6] Kokovay Á., New educational methods and devices (in Hungarian), 2008, http://zeus.nyf .hu/ akokovay/E-learningtovabbkepzes/joktatsiformk.pdf.

[7] A. Vincent, Molecular Symmetry and Group Theory, A Programmed Introduction to Chemical Applications, John Wiley \& Sons Inc., 1976.

[8] L. N. Landa, Algorithms and Programmed Instruction (in Russian), Several Problems of the Theory and Methodology of Programming, Moscow, 1965.

[9] Tóthné Köröspataki Kiss Á., Pedagogical lexicon III. (in Hungarian), Keraban Publishing House, Budapest, 1997.

[10] Karlovitz J., Types of course books, models of course books (in Hungarian), New Pedagogical View 01 (2001).

[11] Komenczi B., Didactika electromagna? The virtual reality of e-learning (in Hungarian), New Pedagogical View 11 (2004).

[12] R. C. Clark and R. E. Mayer, ELearning and the science of instruction, Proven guidelines for consumers and designers of multimedia learning, Pfeiffer, San Francisco, 2003. 
[13] M. J. Rosenberg, E-learning, Strategies for Delivering Knowledge in the Digital Age, McGraw-Hill, USA, 2001.

[14] J. Cole and H. Foster, Using Moodle, Teaching with the Popular Open Source Course Management System, O'Reilly Media Inc., 2008.

[15] docs.moodle.org, Installing Moodle from MoodleDocs, 2010, http://docs.moodle.org/en/Installing_Moodle.

[16] Pántya R. and Mucsics F. L., How can MOODLE e-learning environment support teaching/learning activities?, Contemporary Trends in Teaching and Learning Geography, Romania ISBN 978-973-610-924-9 (2009), 421-432.

[17] K. Thorne, Blended learning, Kogan Page Ltd., London, 2003.

[18] docs.moodle.org, Conditional activities from MoodleDocs, 2010, http://docs.moodle.org/en/Conditional_activities.

[19] docs.moodle.org, Pedagogy from MoodleDocs, 2010, http://docs.moodle.org/en/Pedagogy.

[20] Bessenyei I. and Tóth Zs., The surrounding of constructivist educational environment and the Moodle (in Hungarian), University of West Hungary, Sopron, 2008.

[21] Bakó M., Computer-aided education in teaching practice? (in Hungarian), Educational culture 9 (2000).

[22] Mucsics F. L. and Pántya R., First attempts of launching blended learning courses at Károly Róbert College, Gyöngyös, Thüringisch-Ungarisches Symposium 2009, ISBN 978-3-932886-21-8, Fachhochschule Jena (2009), 144-157.

[23] polihisztor.karolyrobert.hu, 2010, http://polihisztor.karolyrobert.hu/moodle.

[24] Shalfield R., Spenser C., Steel B. and Westwood A., WIN-PROLOG User Guide, Logic Programming Associates Ltd., London, 2007.

[25] Zs. Papp-Varga, P. Szlávi and L. Zsakó, ICT teaching methods - Programming languages, Annales Mathematicae et Informaticae 35 (2008), 163-172.

[26] www.dynamicdrive.com, 2010, http://www . dynamicdrive. com/dynamicindex12/towerhanoi.htm.

[27] www.thinks.com, 2010, http://thinks.com/java/hanoi/hanoi.htm.

[28] R. Pántya and L. Zsakó, Computer-Based Intelligent Educational Program for Teaching Chemistry, Acta Cybernetica 18(4) (2008), 595-613.

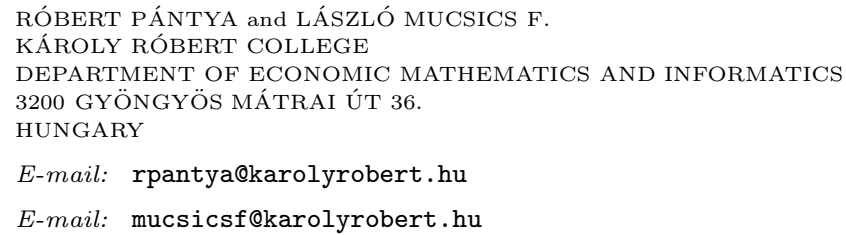

(Received June, 2009) 